\title{
Gene therapy using IL-27 ameliorates Sjögren's syndrome-like autoimmune exocrinopathy
}

\author{
Byung Ha Lee ${ }^{1,2}$, Wendy C Carcamo ${ }^{2}$, John A Chiorini ${ }^{3}$, Ammon B Peck ${ }^{2,4,5}$ and Cuong Q Nguyen ${ }^{4,6}$
}

\begin{abstract}
Introduction: Sjögren's syndrome (SjS) is a systemic autoimmune disease characterized by decreased salivary and lacrimal gland secretions, resulting in severe dry mouth and dry eyes. Recent studies have suggested that $\mathrm{T}_{H} 17$ cells and its signature cytokine $\mathrm{IL}-17$ are involved in the underlying pathogenic mechanisms leading to destructive inflammation and autoimmunity. In the present study, we examined whether IL-27, a natural inhibitor of $T_{H} 17$ activity, could down-regulate or reverse SjS in C57BL/6.NOD-Aec1Aec2 mice, a model of primary-SjS.

Methods: Recombinant serotype 2 adeno-associated viral (AAV2) vectors expressing either IL-27 (rAAV2-IL27) or LacZ (rAAV2-LacZ) were injected into 6 or 14 week-old C57BL/6.NOD-Aec1Aec2 mice. Changes in IL-27, IL-17, and IL-10 cytokine levels in peripheral blood were determined by ELISAs, while flow cytometry analyses were used to quantify cytokine-positive splenocytes. Histological assessment of salivary glands, anti-nuclear autoantibody (ANA) staining, and stimulated saliva flow rates were used to profile SjS disease severity.

Results: Mice systemically treated with intravenous rAAV2-IL27 injections at either 6 or 14 weeks of age exhibited long-term elevated levels of serum IL-27 with concomitantly reduced levels of IL-17 compared with sera from mice injected with rAAV2-LaCZ or saline out to 20 weeks post-inoculation. Most importantly, disease profiles revealed that rAAV2-IL27 treatment had little effect on lymphocytic focus (LF) scores, but resulted in structural changes in LF, lower titers of ANAs with changes in staining patterns, and a less severe clinical disease as determined by saliva flow rates.

Conclusions: These data support the concept that IL-27, when provided exogenously, can induce a suppressive effect on SjS development and thus may be an effective therapeutic agent for regulating $T_{H} 17$ pro-inflammatory activity in autoimmune diseases where the $T_{H} 17$ system has been shown to play an important role in their pathogenesis.
\end{abstract}

\section{Introduction}

Interleukin 27 (IL-27), along with IL-12, IL-23, and IL-35, is a novel cytokine of the IL-6/IL-12 family. It is composed of two subunits: IL-12p40-related Epstein-Barr virus-induced gene 3 (Ebi3) protein and IL-12p35-related p28 protein (p28) [1]. The orphan cytokine receptor WSX-1 (TCCR) and glycoprotein-130 (gp130) make up the heterodimeric signal transducing receptor for IL-27 [2]. IL-27 acts on CD4 $4^{+} \mathrm{T}$ cells and plays a pivotal role as both a pro- and anti-inflammatory cytokine. As a proinflammatory cytokine, IL-27 activates T helper $1\left(\mathrm{~T}_{\mathrm{H}} 1\right)$ responses in the early phases of immunity, in which

\footnotetext{
* Correspondence: nguyenc@ufl.edu

${ }^{4}$ Center for Orphan Autoimmune Disorders, College of Dentistry, University of Florida, Gainesville, FL 32610, USA

Full list of author information is available at the end of the article
}

secretion of interferon-gamma (IFN- $\gamma$ ) is one of the key inflammatory mediators in autoimmunity. The mechanism appears to be the activation of signal transducer and activator of transcription 1 (STAT1) [3]. As an antiinflammatory protein, IL-27 suppresses IL-2, antagonizing IL-6 function and activating expression of suppressor of cytokine signaling (SOCS) protein(s) [4]. In studies with $\mathrm{WSX}^{-1-}$ receptor knockout mice, abnormal signal transduction of IL-27 showed hyper-production of various pro-inflammatory cytokines such as tumor necrosis factor-alpha (TNF- $\alpha$ ) and IL- 6 when challenged by Trypanosoma cruzi or T. gondii [5,6]. Moreover, IL-27 can suppress the expression of forkhead box P3-positive $\left(\right.$ Foxp $3^{+}$) regulatory $\mathrm{T}\left(\mathrm{T}_{\text {reg }}\right)$ cells and act as a negative regulator of human neutrophil function $[7,8]$. Recent

\section{Biomed Central}

(c) 2012 Lee et al.; licensee BioMed Central Ltd. This is an open access article distributed under the terms of the Creative Commons Attribution License (http://creativecommons.org/licenses/by/2.0), which permits unrestricted use, distribution, and reproduction in any medium, provided the original work is properly cited. 
studies also confirmed that IL-27 has anti-tumor effects $[7,9]$.

IL-27 is well known for its inhibitory effects on retinoic acid-related orphan receptor gamma $\mathrm{t}(\mathrm{ROR} \gamma \mathrm{t})$, the transcription factor for $\mathrm{T}_{\mathrm{H}} 17$ cells, by activating both $\mathrm{T}$-bet, the transcription factor for $\mathrm{T}_{\mathrm{H}} 1$ cells, and the STAT1 pathway, thus inhibiting expression of IL-17A (commonly referred to as IL-17) [10]. In addition, WSX-1-deficient mice showed greater susceptibility for experimental autoimmune encephalomyelitis (EAE) in comparison with wild-type control mice and exhibited increased levels of IL-17 [11]. More recent reports have described the capacity of IL-27 to suppress $\mathrm{T}_{\mathrm{H}} 17$ cells by inhibiting $\mathrm{T}_{\mathrm{H}} 17$ cell differentiation, thereby reducing severity of $\mathrm{T}_{\mathrm{H}} 17$ mediated autoimmune diseases [11,12].

Gene delivery using recombinant adeno-associated virus (rAAV)-based vectors has been shown to convey longterm gene expressions in treated hosts [13-16]. Previous studies of gene therapy using AAV have also proven its safety and ability to elicit minimal inflammatory responses in comparison with other types of gene delivery agents [17-20]. Nevertheless, to date, no study using the rAAV system has reported a role for IL-27 in Sjögren's syndrome (SjS). Thus, we examined the effects of IL-27 treatment on $\mathrm{SjS}$ disease of C57BL/6.NOD-Aec1Aec2 mice when delivered either at 6 weeks of age (pre-disease) or at14 weeks of age (clinical disease). Results reported here indicate that IL-27, a potent inhibitor of $\mathrm{T}_{\mathrm{H}} 17$ cell development, may be a useful reagent for treating $\mathrm{SjS}$.

\section{Materials and methods Animals}

C57BL/6.NOD-Aec1Aec2 mice were bred and maintained under specific pathogen-free conditions in the animal facility of Animal Care Services at the University of Florida (Gainesville, FL, USA). Development of the C57BL/6. NOD-Aec1Aec2 mouse and its SjS-like disease phenotype is described elsewhere [21]. Briefly, C57BL/6.NODAec1Aec2 mouse was developed by introducing two genetic regions, one on chromosome 1 (designated Aec2) and the second on chromosome 3 (designated Aec1), derived from the NOD/LtJ mouse, into the SjS-non-susceptible C57BL/6J mouse. All animals were maintained on a 12-hour light-dark schedule and provided food and acidified water ad libitum. At times indicated in the article, mice were euthanized by cervical dislocation after deep anesthetization with isoflurane, and their organs and tissues were freshly harvested for analyses. All experiments and analyses described in this article were performed with male and female mice. The breeding and the use of C57BL/6.NOD-Aec1Aec2 mice for gene therapy study as described here were approved by the University of Florida's Institutional Animal Care and Use Committee and Institution Biosafety Committee.
Recombinant AAV2-IL27 (rAAV2-IL27) vector construction

The serotype 2 adeno-associated viral vector (AAV2) was designed to contain a cytomegalovirus (CMV)/ chicken- $\beta$-actin hybrid promoter, an internal ribosome entry site (IRES), and the inverted terminal repeat sequences (pTR-UF14) (Figure S1A of Additional file 1). To fully recapitulate the functionality of mouse IL-27 cytokine, a rAAV2-IL27 vector was constructed by inserting the genes encoding the two subunits of IL-27 (Ebi3 and p28) into a pTR-UF14 vector. Ebi3 and p28 were generated by polymerase chain reaction (PCR) from murine cDNA by using two pairs of primers (Ebi3: forward 5'-AAACTAGTAGGTCCTTCCCTGGGGCCAGGT-3' and reverse 5'-TTTGATATCAAGGATCCAGTCCCTCTTCAG-3' and p28: forward 5'-AAAAA GCGGCCGCATGGGCCAGGTGACA GGA-3' and reverse 5'-TTTGTCGACTTAGGAATCCCAGGCTGAGCC-3'). Ebi3 and p28 subunits flanked by IRES component were constructed allowing the co-expression of IL-27 subunits driven by the same promoter (Figure S1B of Additional file 1). We used AAV2 vector encoding beta galactosidase (rAAV2-LacZ) as an AAV2 control vector, whose construction was previously reported [22].

\section{Functional activity of IL-27 expressed from the rAAV2- IL27 vector}

rAAV2-IL27 and its backbone (pTR-UF14) plasmids were transfected separately into HEK 293 cells by using TransIT-293 Transfection Reagent (Mirus Bio LLC, Madison, WI, USA) in accordance with the instructions of the manufacturer. After transfection, cell pellet and culture media were collected at different time points up to 48 hours, and expression of the two subunits of IL-27 was measured. Ebi3 was determined by Western blotting by using anti-mouse Ebi3 antibody (Santa Cruz Biotechnology, Santa Cruz, CA, USA), and p28 was detected by enzyme-linked immunosorbent assay (ELISA) by using a Quantikine kit for mouse IL-27 p28 (R\&D Systems, Minneapolis, MN, USA). Biological activity was determined by flow cytometry. Culture supernatants from rAAV2-IL27 or empty AAV2-transfected HEK293 cells were collected (mock). C57BL/6J splenocytes were incubated with mock, IL-6/transforming growth factor-beta (IL-6/TGF- $\beta$ ) for optimal $\mathrm{T}_{\mathrm{H}} 17$ differentiation, and IL$6 /$ TGF- $\beta$ with supernatants of AAV2-IL27 transfected cells at $37^{\circ} \mathrm{C}$ for 5 days. IL- $17^{+}$cells were measured by flow cytometry.

\section{Packaging of recombinant AAV2 (rAAV2) vector particles}

To generate rAAV2 viral particles, adenoviral helper packaging plasmid pDG was used. Plates $(15 \mathrm{~cm})$ with less than $40 \%$ confluent HEK $293 \mathrm{~T}$ cells were co-transfected with either pAAV2-LacZ (control vector) or rAAV2-IL27 
in accordance with standardized methods [23]. Clarified cell lysates were adjusted to a refractive index of 1.372 by the addition of $\mathrm{CsCl}$ and centrifuged at 38,000 revolutions per minute (rpm) for 65 hours at $20^{\circ} \mathrm{C}$. Equilibrium density gradients were fractionated, and fractions with a refractive index of 1.369 to 1.375 were collected. The particle titer was quantified by real-time PCR, and the vector was stored at $-80^{\circ} \mathrm{C}$.

\section{Injections of vectors}

Two different age groups of C57BL/6.NOD-Aec1Aec2 mice were used to take advantage of the pre-disease and clinical disease stages of the animal [24] for the IL-27 gene therapy, thereby aiming to either prevent the onset of the disease or reverse the disease phenotype of $\mathrm{SjS}$ (6-week-old mice for pre-disease stage and 14-week-old mice for clinical disease stage, respectively). Mice were treated systemically with saline or rAAV2-LacZ or rAAV2-IL27, and there were 10 mice (five male and five female) per treatment for each disease stage. Systemic delivery was done via intravenous injection in tail veins. Mice were anesthetized with a ketamine $(100 \mathrm{mg} / \mathrm{mL}$, $1 \mathrm{~mL} / \mathrm{kg}$ body weight; Fort Dodge Animal Health, Fort Dodge, IA, USA) and xylazine $(20 \mathrm{mg} / \mathrm{mL}, 0.7 \mathrm{~mL} / \mathrm{kg}$ body weight; Phoenix Scientific, St. Joseph, MO, USA) cocktail by intraperitoneal injection. Then $50 \mu \mathrm{L}$ of vector solution containing $2 \times 10^{10}$ vector genome (VG) was injected. Control groups received either the same amount of rAAV2-LacZ VG or the same volume of saline. The dosage was chosen on the basis of published studies by others for extensive study of dosage optimization [25-29]. All animals were sacrificed at 20 weeks after delivery. At the time of euthanization, systemic transgene expression was determined by using quantitative real-time PCR (Figure S2 of Additional file 2).

\section{Intracellular cytokine staining and flow cytometry analysis} Single-cell suspensions of spleen cells were prepared from C57BL/6.NOD-Aec1Aec2 mice as described elsewhere [30] and at the ages designated in the text. In brief, spleens were freshly explanted, gently minced through stainless steel sieves, suspended in phosphatebuffered saline (PBS), and centrifuged (1,200 rpm for 5 minutes). Erythrocytes were lysed by a 7 -minute incubation in $0.84 \% \mathrm{NH}_{4} \mathrm{Cl}$. The resulting leukocyte suspensions were washed two times in PBS, counted, and re-suspended in culture media (RPMI 1640 medium, $10 \%$ fetal bovine serum, $2 \mathrm{mM} \mathrm{L}$-glutamine, and $0.05 \mathrm{mM} \beta$-mercaptoethanol) to a density of $2 \times 10^{6}$ cells $/ \mathrm{mL}$. One million cells were pipetted to individual wells of a 24-well microtiter plate pre-coated with antiCD3 (10 $\mu \mathrm{g} / \mathrm{mL}$; BD Pharmingen, San Diego, CA, USA) and anti-CD28 (2 $\mu \mathrm{g} / \mathrm{mL}$; BD Pharmingen) antibodies for T-cell activation. Cells were incubated for 5 hours with Leukocyte Activation Cocktail containing GolgiPlug ( $2 \mu \mathrm{L} / \mathrm{mL}$; BD Pharmingen). Collected cells were fixed and permeabilized by using a Cytofix/CytopermFixation/ Permeabilization kit (BD Pharmingen). The flow cytometry acquisition for intra- and extra-cellular staining was performed following staining with fluorescein isothiocyanate (FITC)-conjugated anti-mouse IL-27 (R\&D Systems), phycoerythrin (PE)-conjugated anti-IL-17 (eBioscience, San Diego, CA, USA), and PE-Cy7-conjugated anti-mouse CD4 (Invitrogen, Carlsbad, CA, USA) for the detection of cytokines from gene-delivered mice. The cells were counted by using a BD ACCURI C6 Flow Cytometer (BD Biosciences, San Jose, CA, USA) and analyzed by FlowJo software (TreeStar Inc., Ashland, OR, USA). $\mathrm{CD}^{+}$and $\mathrm{CD} 4^{+} \mathrm{T}$ cells were gated, and the cells were analyzed for IL- $27^{+}$or IL- $17^{+}$cells.

\section{Cytokine level of peripheral blood}

Measurement of IL-27levels in sera samples was conducted by using a Quantikine kit for mouse IL-27 p28 (R\&D Systems). IL-17, and IL-10 levels are detected using mouse IL-17 and IL-10 ELISA kits (Life Technologies, Grand Island, NY, USA). All procedures were performed in accordance with the instructions of the manufacturers. Readings were carried out by using a Model 680 Microplate Reader (Bio-Rad, Hercules, CA, USA).

\section{Hematoxylin and eosin staining and histological assessment}

Salivary glands, lacrimal glands, liver, lung, and kidney were surgically removed from each C57BL/6.NODAec1Aec2 mouse at the time of euthanasia and placed in $10 \%$ phosphate-buffered formalin for 24 hours. Fixed tissues were embedded in paraffin and sectioned at a thickness of $5 \mu \mathrm{m}$. Paraffin-embedded sections were deparaffinized by immersing in xylene, followed by dehydration in ethanol. The prepared tissue sections were stained with hematoxylin and eosin (H\&E) dye (Histology Tech Services, Gainesville, FL, USA). H\&Estained sections were observed under a microscope for glandular structure and leukocyte infiltration. Lymphocytic foci (LF) were enumerated by three individuals in blinded fashion. LF were defined as aggregates of more than 50 leukocytes quantified per each histological section, and adjacent sections were used for immunofluorescent staining. Stained sections were observed at $\times 6$ magnification by using a Leica MZ8 microscope, and images were obtained with Leica application suite (version 2.4.0.R1; Leica, Wetzlar, Germany).

\section{Immunofluorescence staining}

Tissue sections were deparaffinized, rehydrated, and blocked with hydrogen peroxide. For antigen retrieval, tissue sections were heated to $100^{\circ} \mathrm{C}$ under pressure with 
$10 \mathrm{mM}$ citrate buffer for 15 minutes. The sections were incubated with rat anti-mouse B220 (BD Pharmingen, San Diego, CA, USA) or goat anti-mouse CD3 (Santa Cruz Biotechnology, Inc, Santa Cruz, CA, USA) to detect $\mathrm{B}$ cells and $\mathrm{T}$ cells, respectively, overnight at $4^{\circ} \mathrm{C}$. The sections were washed two times with PBS-Tween and incubated with Texas Red-conjugated rabbit anti-rat IgG (Biomeda, Foster City, CA, USA) for B220 marker and FITC-conjugated rabbit anti-goat IgG (Sigma-Aldrich, St. Louis, MO, USA) for CD3 detection for 30 minutes at room temperature. After additional washes, the slides were treated with mounting medium with 4'-6-diamidino-2-phenylindole (DAPI) (Vector Laboratories, Burlingame, CA, USA). Stained sections were observed at $\times 100$ magnification with a Zeiss Axiovert 200 M microscope, and images were obtained with AxioVs40 software (version 4.7.1.0; Carl Zeiss, Jena, Germany).

\section{Detection of anti-nuclear antibodies in the sera}

Anti-nuclear antibodies (ANAs) in the sera of mice were detected by using an HEp-2 ANA kit (Inova Diagnostics, Inc., San Diego, CA, USA). All procedures were performed in accordance with the instructions of the manufacturer. In brief, HEp-2-fixed substrate slides were overlaid with appropriate mouse sera diluted 1:50, 1:100, 1:200, 1:400, and 1:800. Slides were incubated for 1 hour at room temperature in a humidified chamber. After three washes for 5 minutes with PBS, the substrate slides were covered with Alexa 488-conjugated goat anti-mouse IgG (H/L) (Invitrogen) diluted 1:100 for 45 minutes at room temperature. After three washes, fluorescence was detected by fluorescence microscopy at $\times 200$ magnification by using a Zeiss Axiovert $200 \mathrm{M}$ microscope, and all images were obtained with AxioVs40 software (version 4.7.1.0; Carl Zeiss) with a constant exposure of 0.3 seconds (Carl Zeiss). In this study, three individuals in blinded fashion examined positive staining patterns.

\section{Measurement of stimulated saliva flow}

To measure stimulated saliva flow, each mouse was weighed and injected with a cocktail of isoproterenol $(0.2 \mathrm{mg} / \mathrm{mL})$ and pilocarpine $(0.5 \mathrm{mg} / \mathrm{mL})$ in $100 \mu \mathrm{L}$ of saline by intraperitoneal injection. Saliva was collected for 10 minutes from the oral cavity of individual mice by using a micropipette starting 1 minute after injection of the secretagogue. The volume of each saliva sample was measured. Baseline saliva flow rates (SFRs) were measured a week before the gene therapy, and SFRs were measured every 4 weeks after 8 weeks of post-gene delivery periods until the end of the experiment in each group.

\section{Statistical analyses}

The data are expressed as the mean \pm standard error of the mean. Statistical evaluation was determined by using one-way analysis of variance test with the GraphPad Prism software (GraphPad Software, Inc., La Jolla, CA, USA) or chi-squared test. A $P$ value of less than 0.05 considered statistically significant.

\section{Results \\ rAAV2-IL27 plasmid is highly efficient in producing a functional IL-27 product in vitro}

To determine functional activity of the rAAV2-IL27 plasmid construct, HEK293 cells were transfected with either the rAAV2-IL27 or its backbone, pTR-UF14 plasmid. To control for background, untreated HEK293 cells were cultured in medium containing the transfection reagents only (representing a mock transfection). Forty-eight hours after transfection, cell lysates were prepared and culture media were collected to quantify expression levels by ELISA of both secreted and non-secreted IL-27 protein. As presented in Figure 1A, IL-27 p28 levels were significantly increased in lysates from cells transfected with rAAV2IL27 $(222 \mathrm{pg} / \mathrm{mL})$ in comparison with lysates from either the mock transfected $(24 \mathrm{pg} / \mathrm{mL})$ or pTR-UF14 transfected (22 pg/mL) cells. Similarly, examination of culture media showed elevated levels of IL-27 p28 (272 pg/mL), but IL27 p28 was not detected in either culture media of mock transfected or pTR-UF14 transfected HEK293 cells. Analysis of the cell lysates and culture media also indicated that Ebi3 expression was highly increased in rAAV2-IL27 transfected cells (data not shown).

Biological activity of recombinant IL-27 (rIL-27) secreted by rAAV2-IL27 was determined by using culture media supernatants collected from the rAAV2-IL27 and control by supernatants from pTR-UF14 transfected HEK293 cells or cells alone. C57BL/6J splenocytes cultured in media containing IL- 6 and TGF- $\beta$ supplemented with supernatants containing rIL-27 showed significant decreases in $\mathrm{IL}-17^{+}$cells with concomitant increases in IFN $-\gamma^{+}$cells in comparison with media supplemented with supernatant from either pTR-UF14 or mock transfected cells (Figure 1B). Considered together, these results indicate that the heterodimeric rIL-27 protein is properly expressed by the rAAV2-IL27 vector and is biologically functional in suppressing $\mathrm{T}_{\mathrm{H}} 17$ cells in vitro.

\section{Decreased serum IL-17 levels in mice following rAAV2- IL27 treatment}

To determine the systemic cytokine levels of IL-27 in C57BL/6.NOD-Aec1Aec2 mice following treatment with rAAV2-IL27, rAAV2-LacZ (vector control), or saline (negative control), sera of treated mice were examined 8,12 , and 20 weeks after gene delivery. As indicated in Figure 2A, 6-week-old mice inoculated with rAAV2IL27 exhibited significant increases in IL-27 levels during the subsequent 20 -week observation period, resulting in a threefold increase in comparison with the 


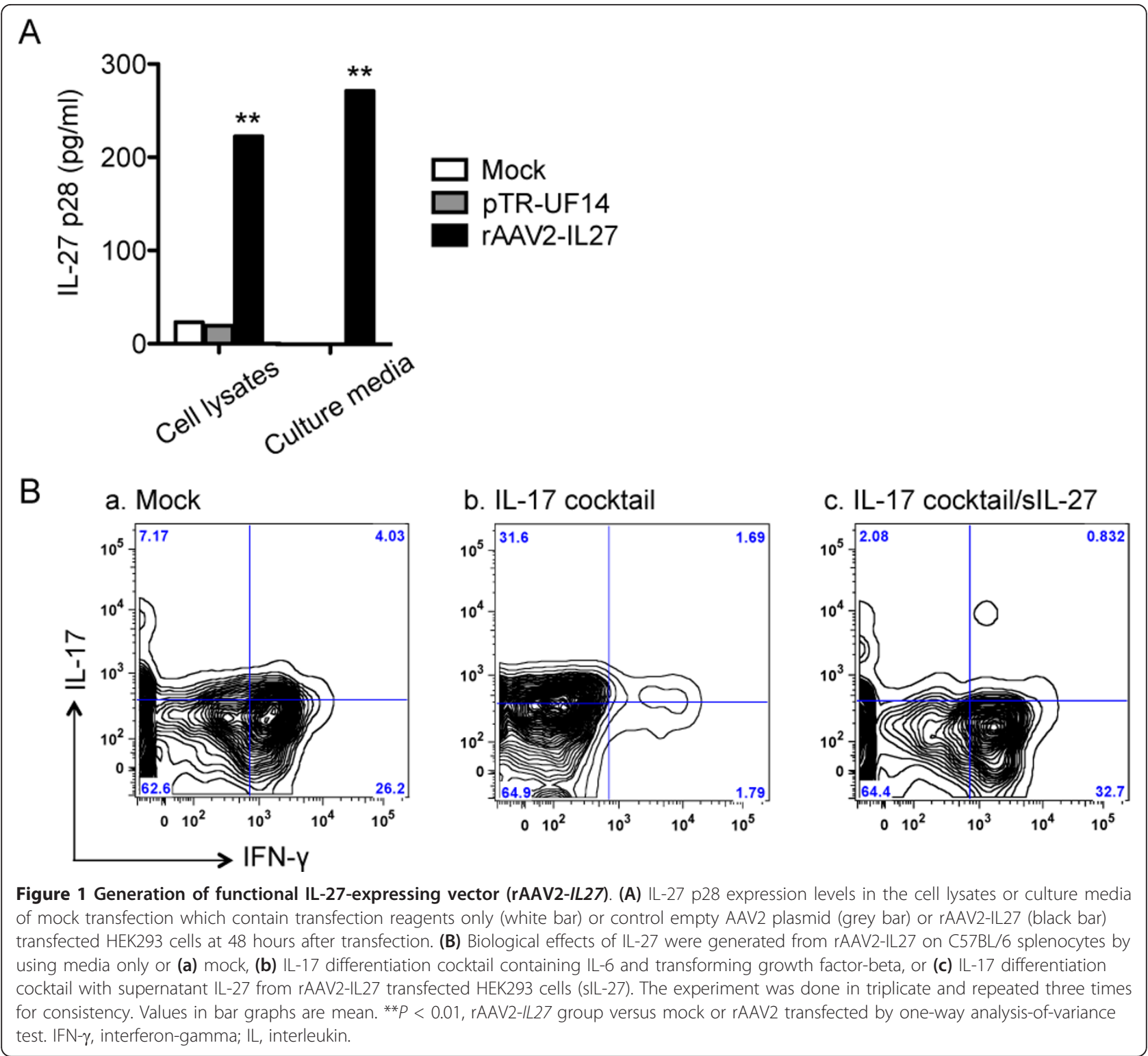

rAAV2-LacZ- or saline-treated control groups (91 versus 34 and $30 \mathrm{pg} / \mathrm{mL}$, respectively). High levels of circulating IL-27 were concomitantly correlated with IL-17 level decreases observed at both 12 and 20 weeks after injection (Figure 2C). Interestingly, IL-10 levels were unaffected by the increased levels of IL-27 (Figure 2E).

Similar, yet more pronounced, results were observed in mice administered rAAV2-IL27 at 14 weeks of age, the time of adaptive immunity onset in the C57BL/6. NOD-Aec1Aec 2 mice. At 8 weeks after injection, mice injected with rAAV2-IL27 showed dramatic increases in the levels of IL-27 in comparison with the rAAV2-LacZor saline-treated control groups (278 versus 175 and 173 $\mathrm{pg} / \mathrm{mL}$, respectively), and these levels were maintained for at least 20 weeks after injection (Figure 2B).
Concomitantly, rAAV2-IL27-treated mice showed reduced levels of IL-17 at both 12 and 20 weeks after vector delivery in comparison with the rAAV2-LacZand saline-treated control groups (Figure 2D), indicating that decreased expression of IL-17 in the sera is correlated with the increased expression of IL-27 in the rAAV2-IL27-treated mice. In contrast to mice treated at 6 weeks of age, IL-10 was highly elevated at 8 weeks after injection in mice treated with rAAV2-IL27 in the clinical disease phase (Figure 2F). These data suggest a direct negative regulation of $\mathrm{T}_{\mathrm{H}} 17$ cells with a corresponding upregulation of IL-10 production, which could further inhibit cytokine productions from $\mathrm{T}_{\mathrm{H}} 1, \mathrm{~T}_{\mathrm{H}} 2$, and $\mathrm{T}_{\mathrm{H}} 17$ cells. Thus, the two disease stages of $\mathrm{SjS}$ respond differently to IL-27 treatment. 


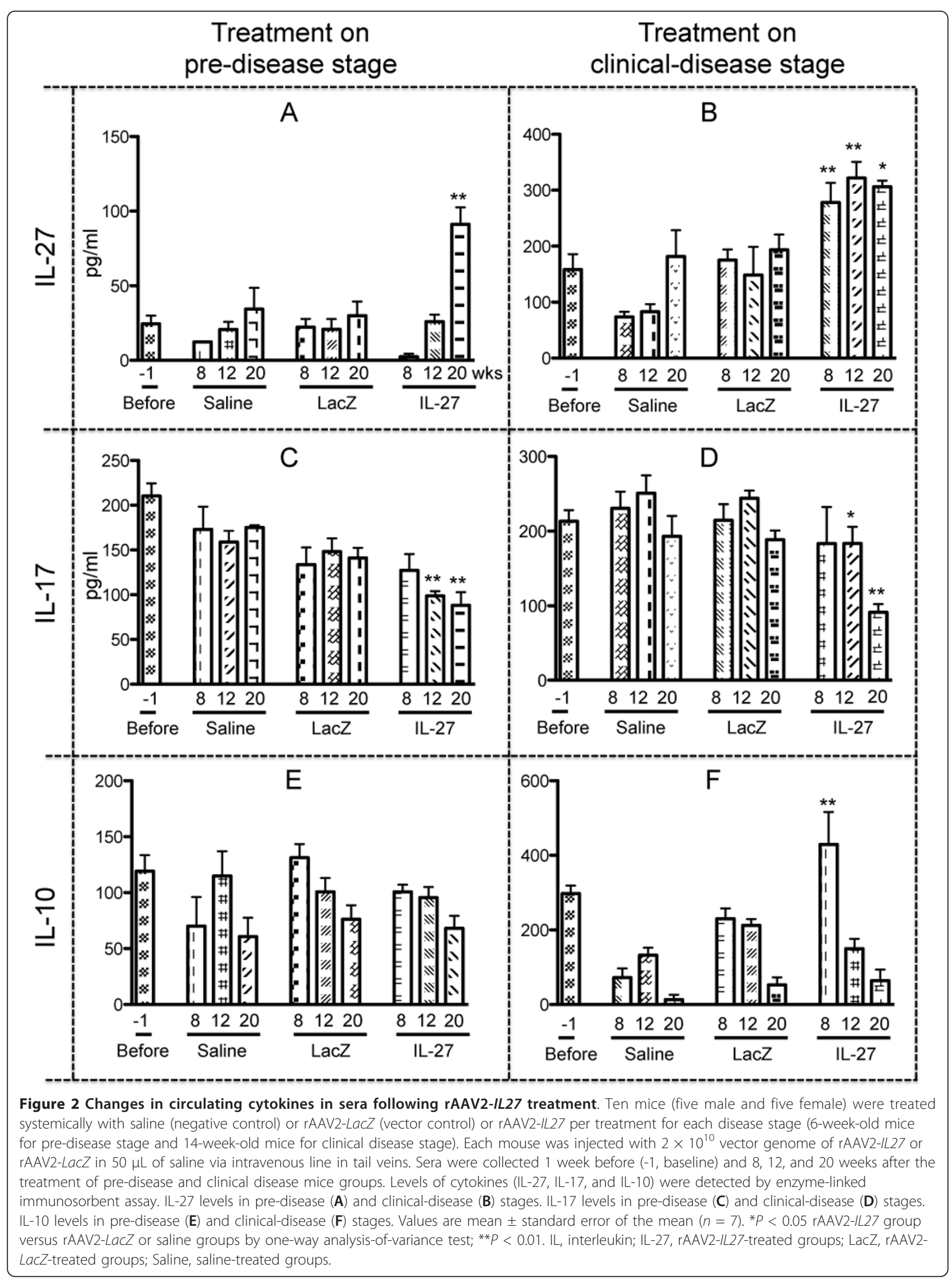


Intravenous injection of rAAV2-IL27 negatively regulates splenic $\mathrm{T}_{\mathrm{H}} 17$ cell functions

As mentioned previously, IL-27 functions to inhibit the activity of $\mathrm{T}_{\mathrm{H}} 17$ cells by negatively regulating the production of IL-17 while directly promoting the production of IFN- $\gamma$ by $\mathrm{T}_{\mathrm{H}} 1$ cells. Since rAAV2-IL 27 was administered intravenously, splenocytes were isolated to examine the systemic effects of the vector on $\mathrm{T}_{\mathrm{H}} 17$ and $\mathrm{T}_{\mathrm{H}} 1$ cells. Splenocytes from mice treated at either 6 or 14 weeks of age were isolated 20 weeks after treatment to profile the levels of IL-27, IFN- $\gamma$, and IL-17 produced by specific T-cell populations. As presented in Figure 3, rAAV2IL27-injected mice showed relative increases in the number of $\mathrm{CD}^{+} \mathrm{CD}^{+} \mathrm{IL}^{-2} 7^{+}$cells, determined by flow cytometry analyses, in comparison with mice treated with rAAV2-LacZ vector or saline. The increases in IL-27 ${ }^{+}$ $\mathrm{T}$ cells were associated with increases in IFN- $\gamma^{+}$cells. Although rAAV2-IL27 treatment of mice at 6 weeks of age resulted in increased numbers of $\mathrm{IL}-27^{+} \mathrm{T}$ cells, there were no differences in IL-17 ${ }^{+} \mathrm{T}$ cells between saline-, rAAV2-LacZ-, and rAAV2-IL27-treated groups, and this was possibly due to the overall low numbers of IL- $27^{+}$ $\mathrm{T}$ cells. In contrast, mice injected with rAAV2-IL27 at 14 weeks of age had decreased numbers of $\mathrm{IL}-17^{+} \mathrm{T}$ cells with a concomitant two- to fourfold increase in IL- $27^{+}$ $\mathrm{T}$ cells over rAAV2-LacZ- and saline-treated groups (Figure 3). These data are consistent with the concept that systemic delivery of IL-27 can regulate the levels of
IL- $17^{+} \mathrm{T}$ cells in the spleen, but high levels of exogenous IL-27 may needed to suppress the levels of IL-17.

\section{Lymphocytic infiltrates in the exocrine glands of rAAV2-IL27-injected mice}

Lymphocytic infiltration present in the salivary glands is one of the main diagnostic markers for $\mathrm{SjS}$. In the C57BL/6.NOD-Aec1Aec2 mouse model, the development and onset of autoimmunity in the exocrine glands are considered the results of acinar cell apoptosis that signals an influx of leukocytes expressing pro-inflammatory cytokines. Salivary gland lymphocytic infiltrates initially are composed of T-cell clusters followed by recruitment of B lymphocytes [31,32]. The migration of specific T-cell populations secreting IL-17 and IL-23 has been shown to directly contribute to the pathogenesis of the disease [33]. Therefore, to determine the effect of rAAV2-IL27 treatment on lymphocytic infiltration in the salivary glands of mice injected at 6 or 14 weeks of age with rAAV2-IL27, freshly explanted, formalin-fixed, paraffin-embedded salivary gland sections were examined after euthanizaton at 20 weeks after treatment.

Representative images of salivary gland infiltrates, shown in Figure 4, reveal the presence of LF composed of both $\mathrm{B}$ and $\mathrm{T}$ lymphocytes, whereas the numbers of LF in the salivary glands were scored for each experimental group (Table 1). As can be seen, rAAV2-IL27-treated mice showed no significant reductions in the number of

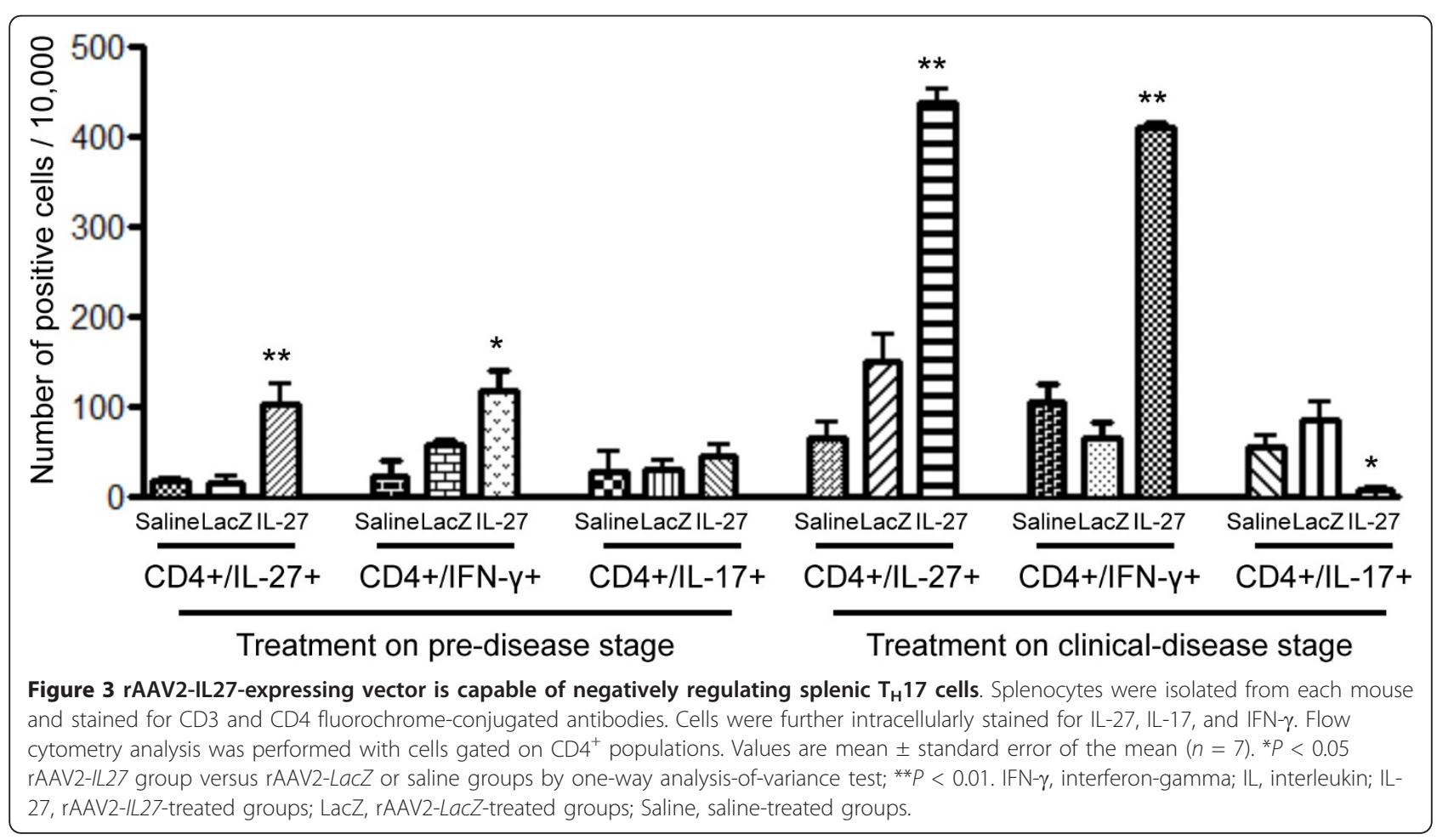




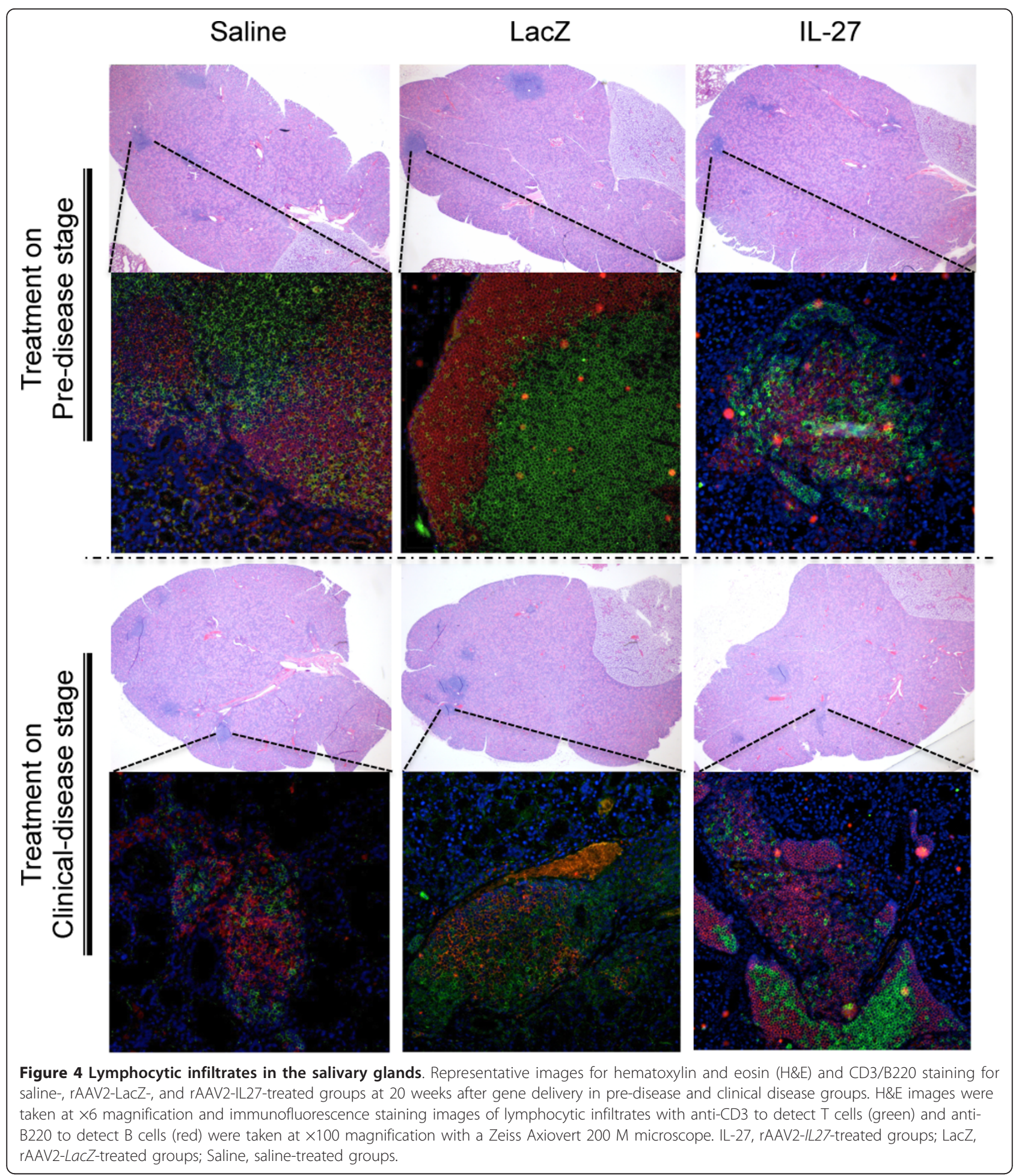

LF in the salivary glands in comparison with either rAAV2-LacZ- or saline-treated mice, irrespectively of the age at which treatment of the mice was carried out. In contrast, lacrimal glands of the rAAV2-IL27-treated mice were noted to have a decrease in the numbers of LF in comparison with saline-treated mice, whereas lacrimal glands explanted from mice treated with rAAV2-LacZ showed slightly lower LF scores. Furthermore, in general, larger infiltrates were found in the rAAV2-LacZ- and saline-treated groups with higher numbers of B cells in comparison with rAAV2-IL27-treated mice. Owing to the intravenous injection of the viral vectors, other 
Table 1 Quantification of lymphocytic infiltrates in the salivary glands of gene-delivered mouse groups

\begin{tabular}{|c|c|c|c|c|c|}
\hline \multirow[t]{2}{*}{ Disease stage } & \multirow[b]{2}{*}{ Treatment } & \multicolumn{2}{|c|}{ Salivary glands } & \multicolumn{2}{|c|}{ Lacrimal glands } \\
\hline & & LF & Mean $^{a}$ & LF & Mean \\
\hline & Saline & $5 / 6^{b}(83 \%)^{c}$ & $2.3 \pm 1.5$ & 4/6 (67\%) & $2.8 \pm 1.3$ \\
\hline \multirow[t]{2}{*}{ Pre-disease } & Lac-Z & $7 / 7$ (100\%) & $3.0 \pm 2.4$ & $6 / 7(86 \%)$ & $1.5 \pm 0.7$ \\
\hline & IL-27 & 6/7 (86\%) & $4.3 \pm 2.2$ & $2 / 7^{d}(29 \%)$ & $2.0 \pm 1.4$ \\
\hline \multirow[t]{2}{*}{ Clinical disease } & Lac-Z & $7 / 7(100 \%)$ & $3.4 \pm 2.4$ & $4 / 7$ (57\%) & $2.5 \pm 1.0$ \\
\hline & IL-27 & $7 / 7$ (100\%) & $3.4 \pm 1.3$ & 2/7 (29\%) & $4.5 \pm 5.0$ \\
\hline
\end{tabular}

${ }^{a}$ Mean lymphocytic foci (LF) score of each gland in mouse \pm standard error of the mean per histological salivary gland section; ${ }^{b}$ number of mice; ${ }^{c}$ percentage of mice; ${ }^{d} P<0.05$ by chi-squared test. IL-27, rAAV2-IL27-treated groups; LacZ, rAAV2-LacZ-treated groups; saline, saline-treated groups.

organs such as liver, lungs, and kidney were also examined for lymphocytic infiltration. However, no significant pathological changes were observed between mice belonging to the different treatment groups (data not shown). These results indicate that systemic injection of rAAV2-IL27 has a positive impact on LF scores in the lacrimal glands, especially when treatment is initiated at 6 weeks of age, but appears to have little or no impact on LF scores in salivary glands.

\section{Intravenous injection of rAAV2-IL-27 treatment alters the anti-nuclear antibody profile in C57BL/6.NOD-Aec1Aec2 mice}

Patients with $\mathrm{SjS}$ often develop ANAs, specifically antiRo (SS-A) or anti-La (SS-B) or both. ANAs that generally show a specked staining pattern when HEp-2 cells are used are highly prevalent in $\mathrm{SjS}$, and the titers of such ANAs are clinically important factors in diagnosing the disease. To identify the presence of ANAs, sera collected from C57BL/6.NOD-Aec1Aec2 mice treated at either 6 or 14 weeks of age with rAAV2-IL27, rAAV2$L a c Z$, or saline were tested for ANA reactivity by using HEp-2 cells. Antibody titers were examined at dilutions of $1: 50,1: 100,1: 200,1: 400$, and 1:800. As presented in Figure 5A, sera from mice injected with rAAV2-IL27 at either age showed comparatively weak or no nuclear speckled antibody staining on the HEp-2 cells (shown at a dilution of 1:400), whereas mice injected with AAV2$L a c Z$ or saline showed strong ANA staining, and this was predominantly a nuclear speckled pattern. Quantification of the nuclear speckled ANA titers clearly revealed that, in mice treated at either age, the titers present in rAAV2-IL27-treated mice were significantly lower than in mice receiving injections of rAAV2-LacZ vector or saline (Figure $5 \mathrm{~B}, \mathrm{C}$ ). Thus, these results suggest that increased levels of IL-27 in sera following rAAV2-IL27 treatment directly affect production or profiles of autoantibodies (or both) in $\mathrm{SjS}$ mice.

\section{Measurement of stimulated saliva flow rates}

To compare SFRs in the C57BL/6.NOD-Aec1Aec2 mice injected with rAAV2-IL27, rAAV2-LacZ, or saline, pilocarpine/isopreterenol-stimulated saliva collections were carried out every 4 weeks starting 8 weeks after treatment, and each value equated to the average baseline SFRs collected from the mice 1 week prior to beginning treatment. As presented in Figure 6, mice treated with either rAAV2-IL27 or rAAV2-LacZ at 6 weeks of age exhibited a relatively rapid loss in SFRs. Mice in the rAAV2-IL27 treatment group, however, showed a slight recovery of SFRs with time, whereas mice in the rAAV2-LacZ treatment group remained low. As expected, mice receiving saline showed a progressive loss in SFRs. These results suggest that the viral vectors per se can influence the SFRs and that IL-27 may be able to reverse the effect, albeit weakly.

In contrast to the above results, mice treated with either rAAV2-IL27 or rAAV2-LacZ at 14 weeks of age exhibited different responses to the treatments (Figure 6B): mice receiving the $\mathrm{rAAV}-L a c Z$ vector again exhibited a rapid loss of SFR, whereas mice receiving the rAAV2-IL27 vector slowly showed minor improvements in their SFRs. Mice receiving saline began showing a slower SFR after about 8 weeks after treatment (or 22 weeks of age), consistent with disease in this model. These results indicate that IL-27 might impact the delayed recovery of SFRs when treatment is done prior to the onset of disease and may partially restore saliva secretion and glandular function at a later stage.

\section{Discussion}

This study was undertaken to examine the effects of IL-27 gene therapy in $\mathrm{SjS}$ by using the C57BL/6.NOD-Aec1Aec2 mouse model of primary $\mathrm{SjS} . \mathrm{SjS}$ is characterized by hyposalivation, autoantibodies in sera, and lymphocytic infiltration in the salivary glands. Previous findings also suggested a role for the IL-23/ $\mathrm{T}_{\mathrm{H}} 17 / \mathrm{IL}-17 \mathrm{~A}$ system in both patients with $\mathrm{SjS}$ and animal models $[33,34]$. Therefore, we hypothesized that IL-27 would have a therapeutic role in treating $\mathrm{SjS}$ and show potential as a therapeutic for the human disease. The results of the present study generally support our hypothesis, showing that IL-27 overexpression by the rAAV2-IL27 vector in C57BL/6.NOD-Aec1Aec2 mice increased saliva secretion and decreased ANA 


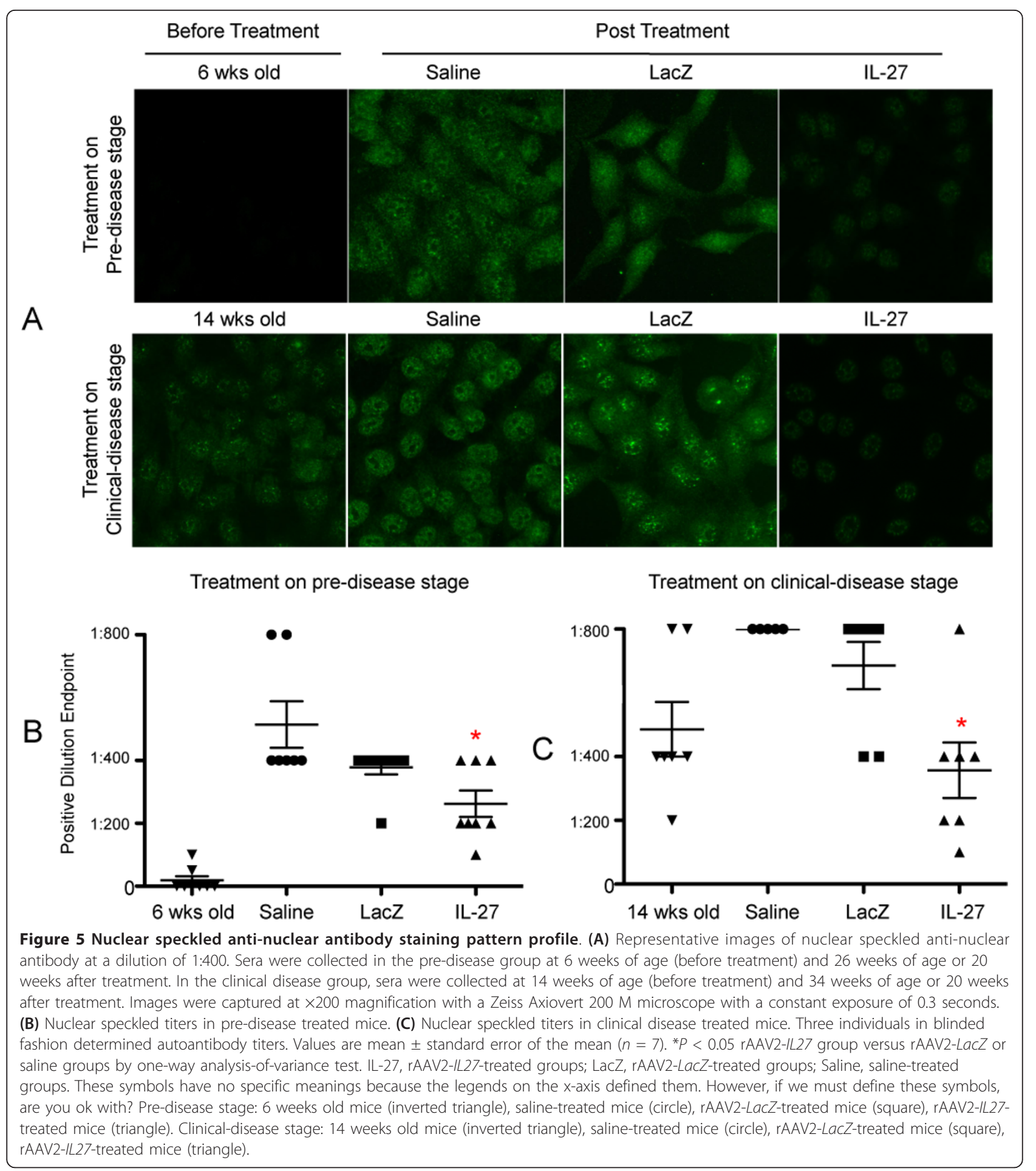

formation despite a lack of differences in LF scores between rAAV-IL27- and rAAV2-LacZ vector-treated mice or saline-treated controls injected at 6 or 14 weeks of age. Interestingly, rAAV2-IL27 treatment at the early clinical disease stage appeared to show a better response than treatment at a pre-disease stage.
The role of IL-27 has been studied, but the underlying mechanism of IL-27 in autoimmune disease, specifically $\mathrm{SjS}$, is still unknown. Although IL-27 has pro-inflammatory functions, which are embodied in activation of IFN $-\gamma$ production from $\mathrm{T}_{\mathrm{H}} 1$ cells, many recent studies are showing anti-inflammatory effects of IL-27 against 


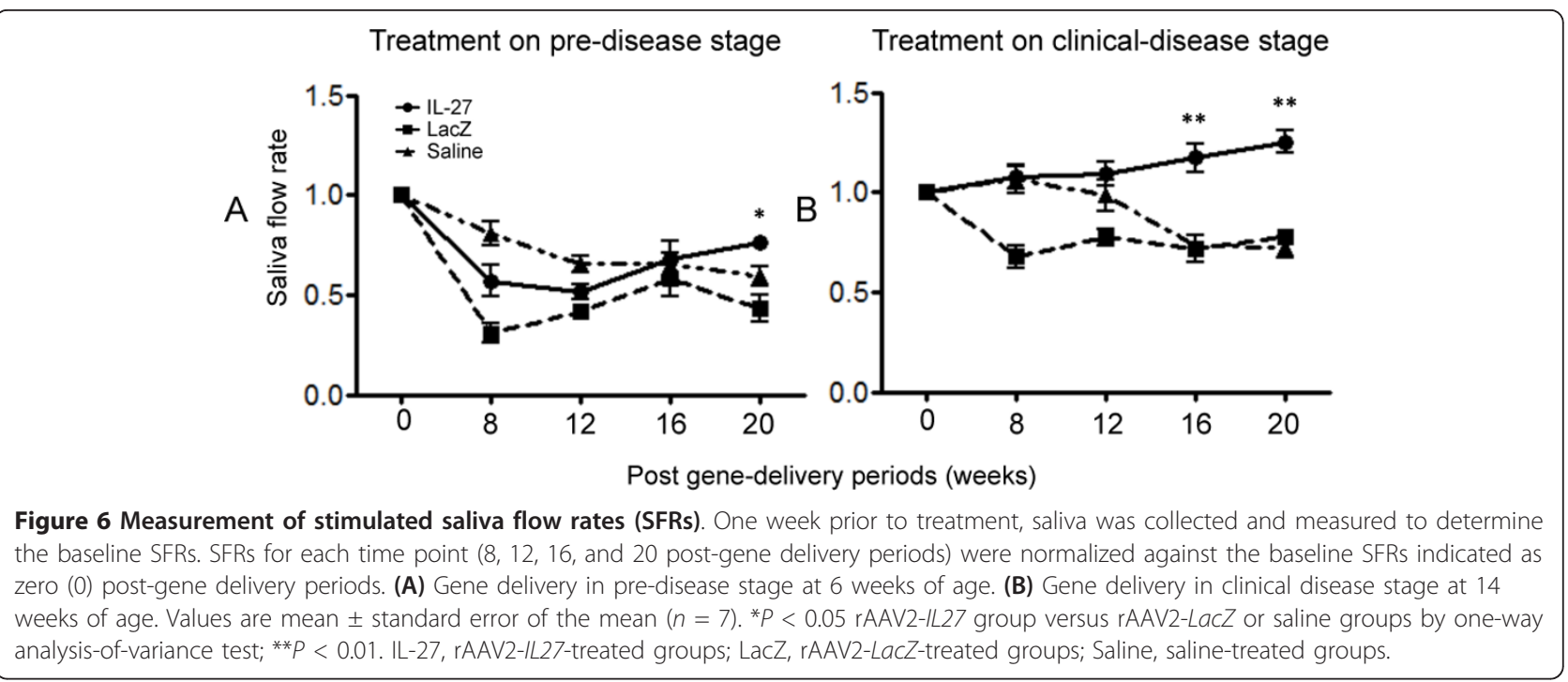

microorganisms and effector $\mathrm{T}$ cells, including $\mathrm{T}_{\mathrm{H}} 17$ cells. Recent studies have also shown that IL-27 is involved in anti-inflammatory functions, especially interfering with TNF- $\alpha$ or $\mathrm{T}_{\mathrm{H}} 17$ cells (or both) in autoimmune diseases, including multiple sclerosis, rheumatoid arthritis, and systemic lupus erythematosus [35-38]. For the potential therapeutic use of IL-27, previous in vivo and in vitro studies have shown that IL-27 can be used as an anti-tumor or anti-viral agent as well as a modulator of autoimmunity [39-43]. IL-27-expressing vectors have been shown to exhibit potent anti-tumor activity in malignancies and metastatic tumors $[9,44,45]$. Therefore, the present study, using IL-27 in a gene therapy protocol, provides evidence that supports its potential effectiveness in autoimmunity.

Our previous study, in which an adenoviral vector was used, demonstrated that overexpression of IL-17 was capable of recapitulating SjS phenotypes (lowered saliva secretion and increased autoantibodies) in normal C57BL/6J mice and, at the same time, showed differential immunological or biological responses depending on the age of mice at the time of treatment [34]. By inducing long-term expression of IL-27 levels by using AAV2, our data showed marked reductions in IL-17 cytokine levels in blood from rAAV2-IL27-injected mice at two different phases of disease onset. Interestingly, there was delayed expression of IL-27 in rAAV2-IL27-treated mice in the innate immune phase in comparison with the expression in the adaptive immune phase. This phenomenon could be attributed to the age of the animals at the time of vector treatment. A study by Bostick and colleagues [46] showed that AAV9 transduction by systemic delivery could be influenced by the age of the animals. These authors found that AAVs exhibited different transduction efficiencies and that adult mice showed higher transduction efficiency than newborn mice. Furthermore, other studies have implicated the 'time lag' effect of AAV2-mediated transgene expression in various tissues, specifically myocardium [47-49]. Zincarelli and colleagues [50] categorized AAV2 as a low-expression and slow-onset virus along with AAV3, 4, and 5 among AAV serotypes 1 to 9 after systemic injection in mice. Our study also showed that the regulation of IL-17 could be directly attributed to the overexpression of an IL-27 transgene, but this could be the indirect systemic effect of IL-27 on other regulatory cytokines and cell types. Although serum IL-27 is elevated at 8,12 , and 20 weeks after treatment in the 14-week treated group, serum IL-17 is markedly decreased at 20 weeks after treatment. A number of factors can regulate the function of IL-17, especially $\mathrm{T}_{\mathrm{H}} 1$ cells releasing IFN- $\gamma$ [4], which was increased in the rAAV2-IL27-treated group (Figure 3). Also, independent roles of IL-27 subunits, p28 and Ebi3, might be critical. A recent study by Stumhofer and colleagues [51] showed that IL-27 p28 alone binds to gp130 as a pro-inflammatory signal antagonist. Although gp130 is the subunit for IL-27 receptor with WSX-1 (IL-27R $\alpha$ ), it is also a subunit for IL-6 receptor, which is involved in $\mathrm{T}_{\mathrm{H}} 17$ cell differentiation. In addition, Ebi3, a cytokine subunit of IL-35, is known for its suppression of $\mathrm{T}_{\mathrm{H}} 17$ cells [52]. Although rAAV2-IL27 vector expresses both p28 and Ebi3, the possibility of independent roles of p 28 or Ebi3 could not be excluded here. Lastly, other cell types (for instance, $\mathrm{Tr}-1$ ) can regulate $\mathrm{T}_{\mathrm{H}} 17$ cells. IL-27 has been shown to be able to stimulate Tr-1 cells, which release IL-10 through STAT1 and STAT3 signaling $[53,54]$. IL-10 is a cytokine that is known for its antiinflammatory function and the inhibitory effect on $\mathrm{T}_{\mathrm{H}} 17$ cells. However, recent studies using IL-27-overexpressing transgenic mice showed an antagonist role of IL-27 on $\mathrm{T}_{\text {reg }}$ cells, another source for IL-10, through IL-2 modulation [55]. Thus, IL-27 may have an effect on the balance of 
Tr-1 cells and $\mathrm{T}_{\text {reg }}$ cells in the mouse or human system. Therefore, multi-factorial regulation of IL-17 might have contributed to the data in this study.

One unique feature of $\mathrm{SjS}$ is the formation of leukocyte aggregates in the salivary and lacrimal glands, referred to as either lymphoepithelial sialadenitis or LF $[56,57]$. At times, these LF appear histologically to be germinal-like centers and may be indicative of a more pronounced and severe hypergammaglobulinemia [58]. Although LF and LF scores are important criteria for clinical disease and depict the level of lymphocytic infiltrations of the exocrine glands, the scores often do not correlate with the severity of disease $[59,60]$. Until recently, it was thought that salivary gland-infiltrating leukocytes were mostly B lymphocytes and $\mathrm{CD} 4^{+} \mathrm{T}_{\mathrm{H}} 1$ cells. However, we recently reported that LF contain significant numbers of $\mathrm{CD}^{+} \mathrm{T}_{\mathrm{H}} 17 \mathrm{mem}$ ory $\mathrm{T}$ cells plus IL-23-producing macrophages or dendritic cells or both [33]. Although the present study shows no difference in mean LF scores between IL-27-treated and AAV2-LacZ vector- or saline-treated controls at the innate or adaptive immune phase, other research has suggested a poor correlation between this marker of disease and salivary gland function [61].

As might be anticipated, only treatment with rAAV2IL27 at the clinical disease stage showed a stable and gradual increase of SFRs compared with baseline SFRs over the course of the experiment, whereas mice treated with rAAV2-IL27 at the pre-disease stage showed slight recovery of glandular function at 20 weeks after treatment. These data are consistent with the serum IL-17 levels, which were significantly downregulated at 20 weeks after treatment for both studied groups. Further investigations are needed to determine the underlying mechanism of how IL-27 influences SFRs, although one possible mechanism is the direct suppression of IL-17 in promoting the formation of spontaneous germinal centers [62], thereby dampening pathogenic autoantibody production [63]. This concept appears to be supported in part by the altered ANA profile and significant decrease in autoantibody titers in rAAV2-IL27-treated mice.

\section{Conclusions}

We have provided a proof of concept that exogeneous IL27 is a potential factor for treating $\mathrm{SjS}$. Although additional research in regard to gene delivery methods and optimal disease time points are needed to further validate the use of rAAV gene transfer, the use of mouse models and systemic delivery of IL-27 provides a unique system to study treatment of autoimmunity at the clinical disease stage, which is applicable for treating patients with established disease. Our results suggest that IL-27 gene therapy could be an effective therapeutic strategy to reverse the symptoms of $\mathrm{SjS}$ and should be further investigated.

\section{Additional material}

Additional file 1: Figure S1. Generation of IL-27 expressing serotype 2 adeno-associated viral vector (AAV2-IL27). A: Diagram of pTR-UF14 vector, which was given by Dr. Sergi Zolotuhkin (Department of Pediatrics, University of Florida College of Medicine) for the back-bone structure of rAAV2-IL27. B: Diagram of rAAV2-IL27. To fully recapitulate the functionality of mouse IL-27 cytokine, a rAAV2-IL27 vector was constructed by inserting the genes encoding the two subunits of IL-27 (Ebi3 and p28) into a pTR-UF14 vector.

Additional file 2: Figure S2. Relative expression of IL-27 p28 mRNA in liver. To compare the transgene expression, livers in each group were collected at the end of experiments (20-week of post delivery periods) and total RNAs were extracted for CDNA synthesis. PCR primers were designed using IDT's PrimerQuestSM (Integrated DNA Technologies Inc., Coralville, IA, USA). Quantitative realtime PCR was performed using the iCycler IQTM multi-color realtime PCR detection system (Bio-Rad Laboratories). The Ct values obtained were normalized to those of $18 \mathrm{~S}$ ribosomal RNA. Level of IL-27 p28 mRNA in LacZ or IL-27 delivered group were normalized against the mRNA level in saline group. (values are mean \pm SEM, ${ }^{*} \mathrm{p}<0.05$ rAAV2-IL27 group versus rAAV2-LacZ or saline groups by one-way ANOVA test).

\begin{abstract}
Abbreviations
AAV2: serotype 2 adeno-associated viral vector; AEC: autoimmune exocrinopathy; ANA: anti-nuclear autoantibody; EAE: experimental autoimmune excephalomyelitis; Ebi3: Epstein-Barr virus-induced gene 3; ELISA: enzyme-linked immunosorbent assay; FITC: fluorescein isothiocyanate; gp130: glycoprotein-130; H\&E: hematoxylin and eosin; IFN- $\gamma$ : interferongamma; IL: interleukin; IRES: internal ribosome entry site; LF: Iymphocytic foci; PBS: phosphate-buffered saline; PCR: polymerase chain reaction; PE: phycoerythrin; rAAV: recombinant adeno-associated virus; rpm: revolutions per minute; SFR: saliva flow rate; SjS: Sjögren's syndrome; STAT: signal transducer and activator of transcription; TGF- $\beta$ : transforming growth factorbeta; $T_{H}$ : $T$ helper; TNF-a: tumor necrosis factor-alpha; $T_{\text {reg: }}$ : regulatory $T$; $V G$ : vector genome.
\end{abstract}

\section{Acknowledgements}

We thank Sergi Zolotuhkin (Department of Pediatrics, University of Florida College of Medicine) for generously providing the AAV2 vectors (pTR-UF14). We thank Tegan $\mathrm{N}$ Lavoie for helping with the flow cytometry analysis used in this study. This work was supported by the Sjögren's Syndrome Foundation (CQN) and Public Health Service (PHS) grant K99 DE018958 (CQN) from the National Institute of Dental and Craniofacial Research. ABP and CQN were supported by PHS grant 1R21AI081952 from National Institute of Allergy and Infectious Diseases.

\section{Author details}

${ }^{1}$ Department of Oral and Maxillofacial Diagnostic Sciences, College of Dentistry, University of Florida, Gainesville, FL 32610, USA. ²Department of Oral Biology, College of Dentistry, University of Florida, Gainesville, FL 32610, USA. ${ }^{3}$ Molecular Physiology and Therapeutics Branch, National Institutes of Dental and Cranial Research, National Institutes of Health, Bethesda, MD 20892, USA. ${ }^{4}$ Center for Orphan Autoimmune Disorders, College of Dentistry, University of Florida, Gainesville, FL 32610, USA. ${ }^{5}$ Department of Pathology, Immunology \& Laboratory Medicine, College of Medicine, University of Florida, Gainesville, FL 32610, USA. ${ }^{6}$ Department of Infectious Disease and Pathology, College of Veterinary Medicine, Gainesville, FL 32608, USA.

\section{Authors' contributions}

$\mathrm{BHL}$ performed vector construction, gene therapy, saliva collections, and disease profiling of the mice and participated in the design of the study, data analyses, and manuscript preparation. WCC carried out histological analysis and ANA staining. JAC helped with AAV2 packaging, study design, and manuscript preparation. ABP and CQN participated in the design of the study, data analyses, and manuscript preparation. All authors read and approved the final manuscript. 


\section{Competing interests}

The authors declare that they have no competing interests.

Received: 21 February 2012 Revised: 2 July 2012

Accepted: 24 July 2012 Published: 24 July 2012

\section{References}

1. Pflanz S, Timans JC, Cheung J, Rosales R, Kanzler H, Gillbert J, Hibbert L, Churakova T, Travis M, Vaisberg E, Blumenschein WM, Mattson JD, Wagner JL, To W, Zurawski S, McClanahan TK, Gorman DM, Bazan JF, de Waal Malefyt R, Rennick D, Kastelein RA: IL-27, a heterodimeric cytokine composed of EBI3 and p28 protein, induces proliferation of naive CD4 (+) T cells. Immunity 2002, 16:779-790.

2. Pflanz S, Hibbert L, Mattson J, Rosales R, Vaisberg E, Bazan JF, Phillips JH, McClanahan TK, de Waal Malefyt R, Kastelein RA: WSX-1 and glycoprotein 130 constitute a signal-transducing receptor for IL-27. J Immunol 2004, 172:2225-2231.

3. Villarino AV, Huang $E$, Hunter CA: Understanding the pro- and antiinflammatory properties of IL-27. J Immunol 2004, 173:715-720.

4. Batten $\mathrm{M}$, Ghilardi $\mathrm{N}$ : The biology and therapeutic potential of interleukin 27. J Mol Med 2007, 85:661-672.

5. Villarino A, Hibbert L, Lieberman L, Wilson E, Mak T, Yoshida H, Kastelein RA, Saris C, Hunter CA: The IL-27R (WSX-1) is required to suppress T cell hyperactivity during infection. Immunity 2003, 19:645-655.

6. Hamano S, Himeno K, Miyazaki Y, Ishii K, Yamanaka A, Takeda A, Zhang M, Hisaeda H, Mak TW, Yoshimura A, Yoshida H: WSX-1 is required for resistance to Trypanosoma cruzi infection by regulation of proinflammatory cytokine production. Immunity 2003, 19:657-667.

7. Li JP, Wu H, Xing W, Yang SG, Lu SH, Du WT, Yu JX, Chen F, Zhang L, Han ZC: Interleukin-27 as a negative regulator of human neutrophil function. Scand J Immunol 2010, 72:284-292.

8. Huber M, Steinwald V, Guralnik A, Brustle A, Kleemann P, Rosenplanter C, Decker T, Lohoff M: IL-27 inhibits the development of regulatory T cells via STAT3. Int Immunol 2008, 20:223-234.

9. Zhu S, Lee DA, Li S: IL-12 and IL-27 sequential gene therapy via intramuscular electroporation delivery for eliminating distal aggressive tumors. J Immunol 2010, 184:2348-2354.

10. Yang J, Yang M, Htut TM, Ouyang X, Hanidu A, Li X, Sellati R, Jiang H, Zhang S, Li H, Zhao J, Ting AT, Mayer L, Unkeless JC, Labadia ME, Hodge M, $\mathrm{Li}$ J, Xiong H: Epstein-Barr virus-induced gene 3 negatively regulates IL17, IL-22 and RORgamma t. Eur J Immunol 2008, 38:1204-1214.

11. Batten M, Li J, Yi S, Kljavin NM, Danilenko DM, Lucas S, Lee J, de Sauvage FJ, Ghilardi N: Interleukin 27 limits autoimmune encephalomyelitis by suppressing the development of interleukin 17producing T cells. Nat Immunol 2006, 7:929-936.

12. Stumhofer IS, Laurence A, Wilson EH, Huang E, Tato CM, Johnson LM, Villarino AV, Huang Q, Yoshimura A, Sehy D, Saris CJ, O'Shea JJ, Hennighausen L, Ernst M, Hunter CA: Interleukin 27 negatively regulates the development of interleukin 17-producing $\mathrm{T}$ helper cells during chronic inflammation of the central nervous system. Nat Immunol 2006, 7:937-945.

13. Flotte TR, Afione SA, Conrad C, McGrath SA, Solow R, Oka H, Zeitlin PL, Guggino WB, Carter BJ: Stable in vivo expression of the cystic fibrosis transmembrane conductance regulator with an adeno-associated virus vector. Proc Natl Acad Sci USA 1993, 90:10613-10617.

14. Conrad CK, Allen SS, Afione SA, Reynolds TC, Beck SE, Fee-Maki M, BarrazzaOrtiz X, Adams R, Askin FB, Carter BJ, Guggino WB, Flotte TR: Safety of single-dose administration of an adeno-associated virus (AAV)-CFTR vector in the primate lung. Gene Ther 1996, 3:658-668.

15. Voutetakis A, Kok MR, Zheng C, Bossis I, Wang J, Cotrim AP, Marracino N, Goldsmith CM, Chiorini JA, Loh YP, Nieman LK, Baum BJ: Reengineered salivary glands are stable endogenous bioreactors for systemic gene therapeutics. Proc Natl Acad Sci USA 2004, 101:3053-3058.

16. Voutetakis A, Zheng C, Mineshiba F, Cotrim AP, Goldsmith CM, Schmidt M, Afione S, Roescher N, Metzger M, Eckhaus MA, Chiorini JA, Dunbar CE, Donahue RE, Baum BJ: Adeno-associated virus serotype 2-mediated gene transfer to the parotid glands of nonhuman primates. Hum Gene Ther 2007, 18:142-150.

17. Wagner JA, Moran ML, Messner AH, Daifuku R, Conrad CK, Reynolds T, Guggino WB, Moss RB, Carter BJ, Wine JJ, Flotte TR, Gardner P: A phase I/II study of tgAAV-CF for the treatment of chronic sinusitis in patients with cystic fibrosis. Hum Gene Ther 1998, 9:889-909.

18. Wagner JA, Messner AH, Moran ML, Daifuku R, Kouyama K, Desch JK, Manley S, Norbash AM, Conrad CK, Friborg S, Reynolds T, Guggino WB, Moss RB, Carter BJ, Wine JJ, Flotte TR, Gardner P: Safety and biological efficacy of an adeno-associated virus vector-cystic fibrosis transmembrane regulator (AAV-CFTR) in the cystic fibrosis maxillary sinus. Laryngoscope 1999, 109:266-274.

19. Flotte TR, Brantly ML, Spencer LT, Byrne BJ, Spencer CT, Baker DJ, Humphries M: Phase I trial of intramuscular injection of a recombinant adeno-associated virus alpha 1-antitrypsin (rAAV2-CB-hAAT) gene vector to AAT-deficient adults. Hum Gene Ther 2004, 15:93-128.

20. Moss RB, Rodman D, Spencer LT, Aitken ML, Zeitlin PL, Waltz D, Milla C, Brody AS, Clancy JP, Ramsey B, Hamblett N, Heald AE: Repeated adenoassociated virus serotype 2 aerosol-mediated cystic fibrosis transmembrane regulator gene transfer to the lungs of patients with cystic fibrosis: a multicenter, double-blind, placebo-controlled trial. Chest 2004, 125:509-521

21. Cha S, Nagashima H, Brown VB, Peck AB, Humphreys-Beher MG: Two NOD Idd-associated intervals contribute synergistically to the development of autoimmune exocrinopathy (Sjögren's syndrome) on a healthy murine background. Arthritis Rheum 2002, 46:1390-1398.

22. Kaludov N, Brown KE, Walters RW, Zabner J, Chiorini JA: Adeno-associated virus serotype 4 (AAV4) and AAV5 both require sialic acid binding for hemagglutination and efficient transduction but differ in sialic acid linkage specificity. J Virol 2001, 75:6884-6893.

23. Grimm D, Kern A, Rittner K, Kleinschmidt JA: Novel tools for production and purification of recombinant adenoassociated virus vectors. Hum Gene Ther 1998, 9:2745-2760.

24. Lee BH, Tudares MA, Nguyen CQ: Sjögren's syndrome: an old tale with a new twist. Arch Immunol Ther Exp 2009, 57:57-66.

25. Shai E, Falk H, Honigman A, Panet A, Palmon A: Gene transfer mediated by different viral vectors following direct cannulation of mouse submandibular salivary glands. Eur J Oral Sci 2002, 110:254-260.

26. Fu H, Muenzer J, Samulski RJ, Breese G, Sifford J, Zeng X, McCarty DM: Selfcomplementary adeno-associated virus serotype 2 vector: global distribution and broad dispersion of AAV-mediated transgene expression in mouse brain. Mol Ther 2003, 8:911-917.

27. Yu CY, Yuan Z, Cao Z, Wang B, Qiao C, Li J, Xiao X: A muscle-targeting peptide displayed on AAV2 improves muscle tropism on systemic delivery. Gene Therapy 2009, 16:953-962.

28. Mah C, Fraites TJ Jr, Zolotukhin I, Song S, Flotte TR, Dobson J, Batich C, Byrne BJ: Improved method of recombinant AAV2 delivery for systemic targeted gene therapy. Mol Ther 2002, 6:106-112.

29. Adesanya MR, Redman RS, Baum BJ, O'Connell BC: Immediate inflammatory responses to adenovirus-mediated gene transfer in rat salivary glands. Hum Gene Ther 1996, 7:1085-1093.

30. Nguyen CQ, Gao JH, Kim H, Saban DR, Cornelius JG, Peck AB: IL-4-STAT6 signal transduction-dependent induction of the clinical phase of Sjogren's syndrome-like disease of the nonobese diabetic mouse. Immunol 2007, 179:382-390.

31. Robinson CP, Cornelius J, Bounous DI, Yamamoto H, Humphreys-Beher MG, Peck AB: Infiltrating lymphocyte populations and cytokine production in the salivary and lacrimal glands of autoimmune NOD mice. Adv Exp Med Biol 1998, 438:493-497.

32. Robinson CP, Cornelius J, Bounous DE, Yamamoto H, Humphreys-Beher MG Peck AB: Characterization of the changing lymphocyte populations and cytokine expression in the exocrine tissues of autoimmune NOD mice. Autoimmunity 1998, 27:29-44.

33. Nguyen CQ, Hu MH, Li Y, Stewart C, Peck AB: Salivary gland tissue expression of interleukin-23 and interleukin-17 in Sjogren's syndrome: findings in humans and mice. Arthritis Rheum 2008, 58:734-743.

34. Nguyen CQ, Yin H, Lee BH, Carcamo WC, Chiorini JA, Peck AB: Pathogenic effect of interleukin-17A in induction of Sjogren's syndrome-like disease using adenovirus-mediated gene transfer. Arthritis Res Ther 2010, 12:R220.

35. Tanida S, Yoshitomi H, Ishikawa M, Kasahara T, Murata K, Shibuya H, Ito H, Nakamura T: IL-27-producing CD14(+) cells infiltrate inflamed joints of rheumatoid arthritis and regulate inflammation and chemotactic migration. Cytokine 2011, 55:237-244.

36. Sweeney CM, Lonergan R, Basdeo SA, Kinsella K, Dungan LS, Higgins SC, Kelly PJ, Costelloe L, Tubridy N, Mills KH, Fletcher JM: IL-27 mediates the 
response to IFN-beta therapy in multiple sclerosis patients by inhibiting Th17 cells. Brain Behav Immun 2011, 25:1170-1181.

37. Murugaiyan G, Mittal A, Weiner HL: Identification of an IL-27/osteopontin axis in dendritic cells and its modulation by IFN-gamma limits IL-17mediated autoimmune inflammation. Proc Natl Acad Sci USA 2010, 107:11495-11500.

38. Rajaiah R, Puttabyatappa M, Polumuri SK, Moudgil KD: Interleukin-27 and interferon-gamma are involved in regulation of autoimmune arthritis. J Biol Chem 2011, 286:2817-2825.

39. Fakruddin JM, Lempicki RA, Gorelick RJ, Yang J, Adelsberger JW, GarciaPineres AJ, Pinto LA, Lane $H C$, Imamichi T: Noninfectious papilloma viruslike particles inhibit HIV-1 replication: implications for immune control of HIV-1 infection by IL-27. Blood 2007, 109:1841-1849.

40. Greenwell-Wild T, Vazquez N, Jin W, Rangel Z, Munson PJ, Wahl SM: Interleukin-27 inhibition of HIV-1 involves an intermediate induction of type I interferon. Blood 2009, 114:1864-1874.

41. Nagai H, Oniki S, Fujiwara S, Xu M, Mizoguchi I, Yoshimoto T, Nishigori C: Antitumor activities of interleukin-27 on melanoma. Endocr Metab Immune Disord Drug Targets 2010, 10:41-46.

42. Pan HF, Tao JH, Ye DQ: Therapeutic potential of IL-27 in systemic lupus erythematosus. Expert Opin Ther Targets 2010, 14:479-484.

43. Kalliolias GD, Gordon RA, Ivashkiv LB: Suppression of TNF-alpha and IL-1 signaling identifies a mechanism of homeostatic regulation of macrophages by IL-27. J Immunol 2010, 185:7047-7056.

44. Hu P, Hu H-D, Chen M, Peng M-L, Tang L, Tang K-F, Matsui M, Belladonna ML, Yoshimoto T, Zhang D-Z, Xiang R, Ren H: Expression of interleukins-23 and 27 leads to successful gene therapy of hepatocellular carcinoma. Mol Immunol 2009, 46:1654-1662.

45. Ho M-Y, Leu S-J, Sun G-H, Tao M-H, Tang S-J, Sun K-H: IL-27 directly restrains lung tumorigenicity by suppressing cyclooxygenase-2-mediated activities. J Immunol 2009, 183:6217-6226.

46. Bostick B, Ghosh A, Yue Y, Long C, Duan D: Systemic AAV-9 transduction in mice is influenced by animal age but not by the route of administration. Gene Therapy 2007, 14:1605-1609.

47. Su H, Huang Y, Takagawa J, Barcena A, Arakawa-Hoyt J, Ye J, Grossman W, Kan YW: AAV serotype-1 mediates early onset of gene expression in mouse hearts and results in better therapeutic effect. Gene Therapy 2006, 13:1495-1502.

48. Chu D, Sullivan CC, Weitzman MD, Du L, Wolf PL, Jamieson SW Thistlethwaite PA: Direct comparison of efficiency and stability of gene transfer into the mammalian heart using adeno-associated virus versus adenovirus vectors. J Thorac Cardiovasc Surg 2003, 126:671-679.

49. Vassalli G, Bueler H, Dudler J, von Segesser LK, Kappenberger L: Adenoassociated virus (AAV) vectors achieve prolonged transgene expression in mouse myocardium and arteries in vivo: a comparative study with adenovirus vectors. Int J Cardiol 2003, 90:229-238.

50. Zincarelli $C$, Soltys $S$, Rengo G, Rabinowitz JE: Analysis of AAV serotypes 1-9 mediated gene expression and tropism in mice after systemic injection. Mol Ther 2008, 16:1073-1080.

51. Stumhofer JS, Tait ED, Quinn WJ, Hosken N, Spudy B, Goenka R, Fielding CA, O'Hara AC, Chen Y, Jones ML, Saris CJ, Rose-John S, Cua DJ, Jones SA, Elloso MM, Grotzinger J, Cancro MP, Levin SD, Hunter CA: A role for IL-27p28 as an antagonist of gp130-mediated signaling. Nat Immunol 2010, 11:1119-1126.

52. Niedbala W, Wei XQ, Cai B, Hueber AJ, Leung BP, McInnes IB, Liew FY: IL-35 is a novel cytokine with therapeutic effects against collagen-induced arthritis through the expansion of regulatory T cells and suppression of Th17 cells. Eur J Immunol 2007, 37:3021-3029.

53. Awasthi A, Carrier Y, Peron JP, Bettelli E, Kamanaka M, Flavell RA, Kuchroo VK, Oukka M, Weiner HL: A dominant function for interleukin 27 in generating interleukin 10-producing anti-inflammatory T cells. Nat Immunol 2007, 8:1380-1389.

54. Wang H, Meng R, Li Z, Yang B, Liu Y, Huang F, Zhang J, Chen H, Wu C: IL-27 induces the differentiation of Tr1-like cells from human naive CD4 + T cells via the phosphorylation of STAT1 and STAT3. Immunol Lett 2011, 136:21-28.

55. Tait Wojno ED, Hosken N, Stumhofer JS, O'Hara AC, Mauldin E, Fang Q, Turka LA, Levin SD, Hunter CA: A role for IL-27 in limiting T regulatory cell populations. J Immunol 2011, 187:266-273.
56. Xu KP, Katagiri S, Takeuchi T, Tsubota K: Biopsy of labial salivary glands and lacrimal glands in the diagnosis of Sjogren's syndrome. J Rheumatol 1996, 23:76-82.

57. Agale SV, D'Costa GF, Hastak MS, Shedge RT: Primary non-Hodgkin's lymphoma of the salivary gland: a spectrum of lymphoepithelial sialadenitis, low-grade B-cell lymphoma of mucosa-associated lymphoid tissue with transformation to high-grade lymphoma. Indian J Pathol Microbiol 2010, 53:364-367.

58. Nordmark G, Alm GV, Ronnblom L: Mechanisms of disease: primary Sjogren's syndrome and the type I interferon system. Nat Clin Pract Rheumatol 2006, 2:262-269.

59. Bombardieri M, Barone F, Pittoni V, Alessandri C, Conigliaro P, Blades MC, Priori $R, M c I n n e s ~ I B$, Valesini $G$, Pitzalis $C$ : Increased circulating levels and salivary gland expression of interleukin-18 in patients with Sjogren's syndrome: relationship with autoantibody production and lymphoid organization of the periductal inflammatory infiltrate. Arthritis Res Ther 2004, 6:R447-456

60. Haga HJ: Clinical and immunological factors associated with low lacrimal and salivary flow rate in patients with primary Sjogren's syndrome. J Rheumatol 2002, 29:305-308.

61. Nikolov NP, Alevizos I, Grisius M, Atkinson J, Cotrim A, Baum BJ, Brahim J: Uncoupling salivary gland dysfunction from inflammation in a large cohort of primary Sjogrens syndrome patients [abstract]. Arthritis Rheum 2009, 60:480.

62. Hsu H-C, Yang P, Wang J, Wu Q, Myers R, Chen J, Yi J, Guentert T, Tousson A, Stanus AL, Le T-VL, Lorenz RG, Xu H, Kolls JK, Carter RH, Chaplin DD, Williams RW, Mountz JD: Interleukin 17-producing T helper cells and interleukin 17 orchestrate autoreactive germinal center development in autoimmune BXD2 mice. Nat Immunol 2008, 9:166-175.

63. Salomonsson S, Jonsson MV, Skarstein K, Brokstad KA, Hjelmstrom P, Wahren-Herlenius $M$, Jonsson R: Cellular basis of ectopic germinal center formation and autoantibody production in the target organ of patients with Sjogren's syndrome. Arthritis Rheum 2003, 48:3187-3201.

doi:10.1186/ar3925

Cite this article as: Lee et al.: Gene therapy using IL-27 ameliorates Sjögren's syndrome-like autoimmune exocrinopathy. Arthritis Research \& Therapy 2012 14:R172.

\section{Submit your next manuscript to BioMed Central and take full advantage of:}

- Convenient online submission

- Thorough peer review

- No space constraints or color figure charges

- Immediate publication on acceptance

- Inclusion in PubMed, CAS, Scopus and Google Scholar

- Research which is freely available for redistribution

Submit your manuscript at www.biomedcentral.com/submit
Ciomed Central 